\title{
Relationship between Maternal Haemoglobin and Fetal Weight
}

\author{
Rana SS, ${ }^{1}$ Sharma S, ${ }^{1}$ Chand A, ${ }^{1}$ Malla $\mathbf{R}^{1}$ \\ ${ }^{1}$ Department of Obstetrics and Gynaeocology, Shree Birendra Hospital, Kathmandu, Nepal.
}

\begin{abstract}
Aims: This study was done to determine the relationship between maternal haemoglobin and fetal weight.
Methods: This study was carried out at Paropakar Maternity and Women's Hospital in 491 primigravidas with full term singleton pregnancy. The study population was divided into two groups, one who had haemoglobin $10 \mathrm{gm} \%$ or more and the other women having haemoglobin less than $10 \mathrm{gm} \%$. Fetal weight as the outcome variable was compared between anaemic and nonanaemic mothers and the relation between maternal haemoglobin and fetal weight was studied.
\end{abstract}

Results: The prevalence of anaemia was $46.2 \%$ out of which $99.5 \%$ had mild anaemia and $0.5 \%$ had moderate anaemia. Mean haemoglobin level was $11.54 \mathrm{gm} \%$ among non anaemic women and mean birth weight was $2.9 \mathrm{~kg}$ in this group whereas mean haemoglobin level was 9.2 $\mathrm{gm} \%$ in anaemic women and mean birth weight was $2.6 \mathrm{~kg}$ in this group and $60 \%$ babies had low birth weight $(<2.5 \mathrm{~kg})$ born to anaemic women (haemoglobin $<10 \mathrm{gm} \%$ ), and $40 \%$ babies had fetal weight $>2.5 \mathrm{~kg}$. Similarly babies born to nonanaemic women (haemoglobin $>10$ gm $\%) 18.1 \%$ had LBW and $81.9 \%$ had fetal weight $>2.5 \mathrm{~kg}$. The risk of low birth weight was 6.8 times higher among anaemic mothers as compared to non- anaemic mothers which was statistically significant with p-value of 0.0001 (OR 6.80 95\% CI, 3.83-12.12).

Conclusions: Anemia in pregnancy is one of the causes for poor fetal outcome. Proper antenatal care and counseling can reduce the incidence of anaemia in pregnancy.

Keywords: anaemia, fetal weight, haemoglobin.

\section{INTRODUCTION}

Anemia in pregnancy is defined as hemoglobin $(\mathrm{Hb})$ concentration less than $11 / 100 \mathrm{ml}$. Because of prevailing socio-economic deprivation in the developing countries, the level is brought down to $10 / 100 \mathrm{ml}^{1}$ Centres for disease control defines anaemia as $\mathrm{Hb}$ less than $11 / 100$ $\mathrm{ml}$ in first and third trimester and less than $10 / 100 \mathrm{ml}$ in second trimester. ${ }^{2}$ In Nepal mild anaemia is $\mathrm{Hb}>7.5 \mathrm{gm} \%$ and $<10 \mathrm{gm} \%$, moderate anaemia is $>5 \mathrm{gm} \%$ and $<7.5 \mathrm{gm} \%$ and severe anaemia is $<5 \mathrm{gm} \%$. $^{3}$

Pregnancy is a state of haemodilution in which there is an intravascular volume expansion. Initially the increase in

\section{CORRESPONDENCE}

Dr Sadikchya Singh Rana

Department of Obstetrics and Gynaeocology,

Shree Birendra Hospital, Kathmandu, Nepal.

Email: drssrana@gmail.com

Phone: 9851078400 plasma volume is larger than the rise in red cell volume and the result is a drop in haemoglobin. Severe anaemia less than $8 \mathrm{gm} \%$ is associated with the birth of low birth weight babies and a major factor influencing haemoglobin concentration in pregnancy is expansion of plasma volume. $^{4}$

The prevalence of anaemia is $51 \%$ for pregnant women globally and 3 to 4 times higher in non-industrialised countries as compared to developed world. Anaemia affects 35 to $75 \%$ women during pregnancy in nonindustrialised countries. It's prevalence in Nepal is $65 \%$ in pregnant women and prevalence of low birth weight is $20.9 \%^{5,6}$

The papers in this journal are published under the terms of the Creative Commons Attribution License. Users are allowed to read, download, copy, distribute, print, search, or link to the full texts of the articles in this journal without asking prior permission from the publisher or the author. 


\section{METHODS}

This was a prospective study done at Paropakar Maternity and Women's Hospital (PMWH), Kathmandu, Nepal. The study population was all the primigravidas who were admitted with full term singleton pregnancy. There were total of 7627 obstetric admissions in the study period, out of which there were 2693 primigravidas. Five hundred pregnant women were enrolled for the study. Exclusion criteria included women with antepartum haemorrhage, anaemia due to acute blood loss, twin or multiple pregnancies, hypertensive disorders of pregnancy, stillbirths and unwillingness to participate in the study. History was taken at the admission followed by general, systemic and obstetric examinations. Blood for haemoglobin was taken from allpatients with full term pregnancy. Haemoglobin level was estimated by cyanmethaemoglobin technique by photoelectric colorimeter. Patient who had got their haemoglobin done two weeks prior to the admission at the laboratory of PMWH was copied directly. Haemoglobin estimation done elsewhere was repeated in the laboratory of the hospital to standardize the result. The patients were divided into two groups, those who have haemoglobin 10 gm\% or more and those having haemoglobin $<10 \mathrm{gm} \%$. Patients having hemoglobin $<10 \mathrm{gm} \%$ were also subdivided into three groups, mild anaemia (>7.5 gm\% and $<10 \mathrm{gm} \%$ ), moderate anaemia ( $>5 \mathrm{gm} \%$ and $<7.5 \mathrm{gm} \%$ ) and severe anaemia ( $<5 \mathrm{gm} \%$ ) according to the PMWH guideline. ${ }^{3}$ Maternal $\mathrm{Hb}$ level $<10 \mathrm{gm} \%$ was considered as anaemia in this study.

SPSS version 10 was used for calculations. Statistical analysis was done using Chi-square test and probability to look for the relationship between maternal anaemia and birth weight. The resultant $p$-value was considered significant if less than 0.05 . Although five hundred cases were initially enrolled in the study, only four hundred ninety one of them were finally analysed because of drop out.

\section{RESULTS}

The prevalence of anaemia was $46.2 \%$ out of which $99.5 \%$ had mild anaemia and $0.5 \%$ had moderate anaemia. The lowest range of haemoglobin among anaemic was 8.2 gm\% and the highest range of haemoglobin among non anaemic was $13.8 \mathrm{gm} \%$ in the present study (Table 1 ).

Table 1. According to WHO classification of anaemia.

\begin{tabular}{llll}
\hline $\begin{array}{l}\text { Type of } \\
\text { anaemia }\end{array}$ & $\begin{array}{l}\text { Haemoglobin } \\
\text { value in } \mathrm{gm} / \mathrm{dl}\end{array}$ & Number & Percentage \\
\hline Normal & 11.1 and above & 264 & 53.8 \\
Mild & $8.1-11$ & 226 & 46 \\
Moderate & $5.1-8$ & 1 & 0.2 \\
Severe & $<5$ & - & - \\
\hline
\end{tabular}

Almost $54 \%$ of the study population was not anaemic and only $46.2 \%$ of the study population was anaemic. Out of all the anaemic patients $99.5 \%$ had mild anaemia and $0.5 \%$ had moderate anaemia.

Mean $\mathrm{Hb}$ level was $11.54 \mathrm{gm} \%$ among non-anaemic and mean birth weight was $2.9 \mathrm{~kg}$ in this group where as mean haemoglobin level was $9.2 \mathrm{gm} \%$ in anaemic women and mean birth weight was $2.6 \mathrm{~kg}$ in this group (Table 2).

Table 2. Maternal haemoglobin vs fetal weight $(n=491)$.

\begin{tabular}{lllll}
\hline $\begin{array}{l}\text { Maternal } \\
\text { haemoglobin } \\
\text { level }\end{array}$ & Patients & Percentage & $\begin{array}{l}\text { Mean } \\
\text { birth } \\
\text { weight }\end{array}$ & $\begin{array}{l}\text { Mean } \\
\text { haemoglobin }\end{array}$ \\
\hline$\geq 10$ gm\% & 421 & 85.7 & $\begin{array}{l}2.94 \pm 11.54 \pm 1.01 \\
0.39\end{array}$ \\
& & & $2.60 \pm 9.20 \pm 0.44$ \\
gm\% & 70 & 14.3 & 0.43 & \\
$5-<7.5$ gm\% & 0 & 0 & & \\
$<5$ gm\% & 0 & 0 & & \\
\hline
\end{tabular}

Mean haemoglobin level among non anaemic was 11.54 gm\% and mean birth weight was $2.9 \mathrm{~kg}$ among non anaemic. Mean haemoglobin was $9.2 \mathrm{gm} \%$ in anaemic women and mean birth weight was $2.6 \mathrm{~kg}$ in anaemic women.

Majority of the mothers (68.6\%) had taken iron during their antenatal period and majority $(74.3 \%)$ had taken extra diet (Table 3 and 5) and 60\% had LBW ( $<2.5 \mathrm{~kg}$ ) born to anaemic women and $40 \%$ had fetal weight $>2.5 \mathrm{~kg}$. Similarly babies born to non-anaemic women $18.1 \%$ had low birth weight (LBW) and $81.9 \%$ had fetal weight $>2.5 \mathrm{~kg}$.

Table 3. Fetal weight in relation to extra diet $(n=491)$.

\begin{tabular}{lll}
\hline Extra diet & $\begin{array}{l}\text { Low birth weight } \\
(<\mathbf{2 . 5} \mathbf{~ k g})\end{array}$ & $\begin{array}{l}\text { Normal birth } \\
\text { weight }(>\mathbf{2 . 5} \mathbf{~ k g})\end{array}$ \\
\hline Yes & 100 & 326 \\
No & 18 & 47 \\
\hline
\end{tabular}

Majority of the study population had taken extra diet and approximately $1 / 3$ rd of these mothers had low birth weight despite taking extra diet during their antenatal period. The birth weight of the babies among mothers who had extra diet and those who did not have extra diet was statistically not significant. ( $p$ value $=0.45, x^{2}=0.55$ ) 
Table 4. Maternal Hb versus fetal weight $(n=491)$.

\begin{tabular}{|c|c|c|c|c|c|}
\hline $\mathrm{Hb}$ & $\begin{array}{l}<2.5 \\
\text { birth } \\
\text { weight }\end{array}$ & $\begin{array}{l}>2.5 \\
\text { birth } \\
\text { weight }\end{array}$ & Total & $\begin{array}{l}\text { Crude } \\
\text { OR } \\
(95 \% \mathrm{Cl})\end{array}$ & $\begin{array}{l}\text { Adjusted } \\
\text { OR } \\
(95 \% \mathrm{CI})\end{array}$ \\
\hline $\begin{array}{l}\text { Haemoglobin } \\
<10 \text { gm\% }\end{array}$ & 42 & 28 & 70 & $\begin{array}{l}6.80 \\
(3.83 \\
12.12)\end{array}$ & $\begin{array}{l}6.93 \\
(4, \\
12.02)^{*}\end{array}$ \\
\hline $\begin{array}{l}\text { Haemoglobin } \\
>10 \text { gm\% }\end{array}$ & 76 & 345 & 421 & & \\
\hline
\end{tabular}

The risk of low birth weight was 6.8 times higher among anaemic mothers as compared to non anaemic mothers. $\left(p=0.0001, x^{2} 57.84\right)$

After adjusting for the extra diet during pregnancy with maternal haemoglobin and fetal weight, the odds ratio or was 6.93 , slightly higher than the crude odds ratio. Significant association between fetal weight and haemoglobin was found even after adjustment $(p=0.0001)$. Again Chi Square test of homogeneity confirmed that there was no interaction between haemoglobin and extra diet $(p=0.80)$ on the risk of having low birth weight.

Table 5. Factors associated with anaemia.

\begin{tabular}{lll}
\hline Factors & & \\
\hline Residence & Number of patients & Percentage \\
Urban & 19 & 27.1 \\
Rural & 51 & 72.9 \\
ANC & Number of patients & Percentage \\
Nil & 67 & 13.6 \\
$1-3$ & 275 & 56 \\
$>4$ & 149 & 30 \\
Iron intake & Number of patients & Percentage \\
Yes & 48 & 68.6 \\
No & 22 & 31.4 \\
Extra diet & Number of patients & Percentage \\
Yes & 52 & 74.3 \\
No & 18 & 25.7 \\
\hline
\end{tabular}

Most of the mothers were from rural area in the study population. Majority of the mothers had visited antenatal clinic. Frequency of ANC was 1-3 visits in most of the mothers. Majority of the mothers had taken iron and extra diet during their pregnancy in the study population.

The risk of low birth weight were 6.8 times higher among anaemic mothers as compared to non-anaemic mothers which was statistically significant $(p=0.0001)$ \{OR $6.80,95 \%$ Cl, 3.83-12.12\}[Table 4].

\section{DISCUSSION}

Anaemia in pregnancy is an important preventive cause of maternal and perinatal morbidity and mortality. Prepregnancy and postpartum anaemia occurs worldwide; particularly in developing countries where it accounts for maternal and infant morbidity and mortality. ${ }^{4}$

WHO reports that from $35 \%$ to $75 \%$ of pregnant women in developing countries and $18 \%$ of women from industrialised countries are anaemic. Prevalence of anaemia is $43 \%$ in women in developing countries and $12 \%$ in women in wealthier regions. ${ }^{5}$ The prevalence of anaemia in pregnant women is $65 \%$ in Nepal, $53 \%$ in Bangladesh, $88 \%$ in India, $39 \%$ in Sri Lanka, $68 \%$ in Bhutan and $20 \%$ in Maldives. ${ }^{6}$

The prevalence of anaemia according to who classification was $46.2 \%$ in this study out of which $99.5 \%$ had mild anaemia, $0.5 \%$ had moderate anaemia. No case was found with severe anaemia (Table1). Similar prevalence of anaemia was found by Shaukat et al. ${ }^{7}$ where $47 \%$ mothers were anaemic and $9 \%$ were severely anaemic. Tuladhar $^{8}$ also reported an incidence of $41.1 \%$ among them $71.4 \%$ had mild anaemia, $24.4 \%$ had moderate anaemia and $4.2 \%$ had severe anaemia. The prevalence of moderate anaemia was less in this study, which could be due to adequate antenatal care (ANC), majority of the mothers (68.6\%) had taken iron during their antenatal period and majority (74.3\%) had taken extra diet.

In this study mean $\mathrm{Hb}$ level was $11.5 \mathrm{gm} \%$ among nonanaemic and mean birth weight was $2.9 \mathrm{~kg}$ in this group whereas mean haemoglobin level was $9.2 \mathrm{gm} \%$ in anaemic women and mean birth weight was $2.6 \mathrm{~kg}$ in this group (Table2). Similar findings were reported by Nahum et al. ${ }^{9} \mathrm{~T}$ hey also found mean birth weight of $3.5 \mathrm{~kg}$ in non-anaemic women with mean $\mathrm{Hb}$ concentrations of $11.6 \mathrm{gm} \%$. Malhotraet $\mathrm{al}^{10}$ also found that the mean birth weight was maximum with $\mathrm{Hb}$ values of 9.6-10.5\% category.

In this study $60 \%$ had LBW $(<2.5 \mathrm{~kg}$ ) born to anaemic womenand $40 \%$ had fetal weight $>2.5 \mathrm{~kg}$. Similarly among babies born to non-anaemic women $18.1 \%$ had LBW and $81.9 \%$ had fetal weight $>2.5 \mathrm{~kg}$. This difference was statistically significant $(p<0.0001)$. The crude odds ratio for low birth weight among anaemic mothers was 6.80 (95\% Cl, 3.83-12.12). The risk of low birth weight was 6.8 times higher among anaemic mothers as compared to non anaemic mothers which was statistically significant $(p=0.0001)$ (Table4). Godfrey et $a^{11}$ also suggested a link between maternal anaemia with low birth weight.

Brabinet $\mathrm{a}^{12}$ reported moderate anaemia had a relative risk of low birth weight of 0.76-2.96 but no cases were found with moderate anaemia in this study. Roy et al ${ }^{13}$ has reported the incidence of low birth weight in anaemic women varying from $27.5 \%$ to $79.5 \%$ in India. 
Molaet al $^{14}$ from Papua New Guinea have reported $40 \%$ whereas Tuladhar ${ }^{8}$ from Nepal reported as incidence of $41.1 \%$. Diejomoahet $\mathrm{al}^{15}$ have reported an incidence of low birth weight in anaemic women as $7 \%$. Similarly Lone ${ }^{16}$ reported the risk of preterm delivery and low birth weight among the anaemic women was 4 and 1.9 times more respectively than the non-anaemic women. Shaukat et $\mathrm{al}^{7}$ also found that low birth weight deliveries were significantly associated with maternal anaemia. Severe maternal anaemia was associated with further problems like prematurity, neonatal sepsis, hypoglycaemia, hypocalcaemia and respiratory distress syndrome.

Bondevik et $\mathrm{al}^{17}$ also reported severe anemia was associated with a significantly increased risk of low birth weight and preterm delivery among 1400 pregnant women attending Patan Hospital. In a study by El Guindi et $\mathrm{al}^{18}$, maternal anaemia was significantly associated with increased low birth weight (2933 gm versus 3159 gm).In this study the low birth weight was considered as outcome variable for anaemic women after adjusting for possible confounders such as extra diet, there was a significant association between maternal haemoglobin and fetal weight $(p=0.0001)$. Moreover, Chi Square test of homogeneity confirmed that there was no interaction between haemoglobin and extra diet on the risk of having low birth weight $(p=0.80)$.

\section{CONCLUSIONS}

Anaemia in pregnancy remained a major contributing factor for maternal and perinatal morbidity and mortality. Among various risks factors, maternal anaemia posed a significant effect in producing low birth weight babies.

\section{REFERENCES}

1. Cuningham FG, Norman GF, Leveno JK, Gilstrap CL, Hauth CJ, Katherine WD. Haematological disorders. In: Williams Obstretics. 21st ed. USA: McGraw-hills; 2001;pp.1252-68.

2. Philip S, Geoffrey S. Medical disorders in pregnancy. In: Chamberline G, Steev P, editors. Turnbull's Obstetrics. 3rd ed. London: Churchill Livingston; 2002.pp.292-4.

3. Digdarshan. Paropakar Shree Panchlndra RajyaLaxmi Devi PrasutiGriha. 40th anniversary.Kathmandu: PMWH; 1999.
4. Steer PJ. Maternal haemoglobin concentration and birth weight. Am J Clin Nutr. 2000;71:1258-87.

5. WHO. World Health Statistics Quarterly. Geneva:WHO;1980. pp.197-224.

6. UNICEF. Reduction of low birth weight, a South Asia priority. Kathmandu: Unicef Rosa;2002.

7. Shaukat M, Zaheen A, Zaanam Q, Sheikh GA. Maternal anaemia, perinatal morbidity and mortality. J Pak Paed Assoc. 2002;80:88-98.

8. Tuladhar H. Anaemia in adolescent pregnancy. JNMC. 2000 Jan;2(1):19-21.

9. Nahum GG, Stanislaw H. High altitude exposure during pregnancy and low birth weight. J Rep Med. 2004;49(4):297305.

10. Malhotra M, Sharma JB, Batra S, Sharma S. Perinatal outcome in varying degrees of anemia. Int J Gyanaecol and Obstet. 2002;9(2):93-100.

11. Godfrey KM, Reman WG, Barker DJP, Osmond C. The effect of maternal anaemia and iron deficiency on the relation of fetal weight to placental weight. $\mathrm{Br} J$ Obstet Gynaecol. 1991;98:886.

12. Brabin BJ, Kalanda BF, Verhoeff FH, Chimsuku LH, Broadhead RL. Low birth weight and fetal anaemia as risk factors for infant morbidity in rural Malawi. Malawi Med J. 2009 Jun;21(2):69-74.

13. Roy S, Chakravarty PS. Maternal and perinatal outcome in severe anaemia. J Obstet Gynaecol India. 1992Dec;42(6):7437.

14. Mola G, Permezel M, Amoa AB, Klufio CA. Anaemia and perinatal outcome in port Moresby. Aust N Z J Obstet Gynaecol. 1999 Feb;39(1): 31-4.

15. Diejomaoh ME, Abdulaziz A, Dekile AD. Anaemia in pregnancy. Int J Gynaecol Obstet. 1999 Feb;65: 299-301.

16. Lone FW, Qureshi RN, Emanuel F. The relationship between maternal anaemia and perinatal outcome. East Medit Health Jour. Nov 2004;110(60): 801-7.

17. Bondevik GT, Lie RT, Ulstein M, Kvale G. Maternal characteristics on haematological status and effect of low birth weight. Acta Obstet Gynaecol Scand. May 2007;80(5):402-8.

18. El Guindi W, Pronost J, Carles G, Largeaud M, El Gareh N Effects of severe maternal anaemia on pregnancy outcome. J Obstet Gynaecol Biol Reprod. Oct 2004;33:506-9. 